\title{
ON THE TRANS-SIBERIAN WITH SYLVESTER STALLONE: NATIONAL IDENTITY AND BRAND IDENTITY IN POST-SOCIALIST RUSSIA
}

In our short paper we look at how certain brands in post-socialist Russia appeal to consumers' patriotism in order to build brand identity. In order to ensure thematic coherence, we restrict our discussion to the alcohol sector. In the first part, we analyse the packaging of certain vodka and brandy brands. Our focus then shifts to beer and specifically the Facebook page of AB-InBev's 'Siberian Crown' brand (entitled 'The Map of Russian Pride'). Our paper is conceptual, and we use a visual studies methodology following Schroeder (2002) and Manning (2010). As we demonstrate, a number of brands in today's Russia generate certain types of myths, both about Russia and Russianness and - by extension - about themselves as brands. They do so by recreating the past, or rather, by carefully selecting from that past those elements which contribute to the grand narrative that is both the brand, and the nation. Our paper's contributions lie in a number of areas. First of all, it adds to the literature on social media networks, and especially to discussions of the role those networks play in branding. Second, it explores the relationship between building brand legitimacy and (re)constructing national identity. Third, and perhaps most importantly, it extends the pioneering work on 'iconic' branding by Holt (2006) into a non-Western context. Given our findings, more work clearly needs to be done on the difference that social networks make to brands, on the role they playboth in legitimizing the brand and in promoting myths of national identitynot just in Russia but in a wide variety of markets.

Keywords: packaging, social media, branding, nostalgia, Russia, alcohol.

В этой короткой статье мы рассматриваем, как при создании брендовой идентичности в постсоветской России происходит обращение к патриотическим чувствам потребителей. В рамках темы исследование ограничивается сферой алкогольной продукции. В первой части статьи анализируется оформление упаковки различных видов водки и бренди. Далее мы обращаемся к анализу пивной продукции, а именно к странице бренда «Сибирская корона», принадлежащего международной пивоваренной корпорации $A B \operatorname{InBev}$, в социальной сети Facebook (страница озаглавлена 'The Map of Russian Pride'). Наша статья носит концептуальный характер, и мы прибегаем к методологии визуального исследования, опираясь на труды Шредера (2002) и Маннинга (2010). В статье показано, что некоторые бренды в современной России порождают определенные виды мифов о России и русскости и в итоге - о самих себе как брендах. Это делается путем обращения к прошлому или, скорее, методичным 
выбором элементов прошлого, которые вписываются в великое повествование, охватывая и бренд, и нацию. Статья затрагивает разные области. Во-первых, она касается исследований социальных сетей, в особенности посвященных обсуждению роли, которые такие сети играют в построении образа бренда. Во-вторых, исследует соотношение между построением легитимности бренда и (вос-)становлением национальной идентичности. И, возможно, самое главное, статья расширяет посвященный иконическим брендам новаторский труд Холта (2006) рассмотрением незападного контекста. Результаты анализа показывают, что дальнейшее исследование должно быть посвящено изменениям, которые вызывают в образе бренда социальные сети, а также роли, которую они играют в процессе узаконивания бренда и продвижении мифа о национальной идентичности - не только на российском, но и на других рынках.

Ключевые слова: упаковка; социальные СМИ; брендировавание; ностальгия; Россия; алкоголь.

'Been away so long I hardly knew the place, Gee, it's good to be back home!' The Beatles. Back in the USSR

\section{Introduction}

The aim of our paper is to examine how certain brands in Russia exploit consumers' patriotism and nostalgia in order to build identity and gain legitimacy. This paper, a revised and extended version of Roberts [2013], is part of a larger book-length study into the aesthetics of branding in Russia, following Schroeder [2002]. The main focus of our study will be the Facebook page of the beer 'Sibirskaya korona'. Before looking at social media, however, we should like to say something about packaging design in Russia. This is because we believe that, from a branding point of view, there are important parallels between the material culture of packaging and the immaterial culture of social media. In particular, we should like to take up the central themes of two articles published recently on the Material World blog by Makarenko and Borgerson [2009] and Glass [2012].

It could be argued, of course, that packaging is not 'material culture' in the usual sense of the word. In some sense it is a hybrid phenomenon, neither immaterial (like the brand), nor material (like the product [see Manning, 2010; Heilbrunn and Barré]). We would maintain, however, that packaging is indeed part of material culture in the sense described by Woodward: 'In its popular scholarly usage, the term "material culture" is generally taken to refer to any material object (e. g. shoes, cup, pen) or network of material objects (e. g. house, car, shopping mall) that people perceive, touch, use, handle, carry out social activities within, use or contemplate' [Woodward, p. 14]. Packages are indeed objects, since they are handled, and - especially in the cases which we shall be looking at - they are aesthetic objects designed to be contemplated [see for example Borgerson, Schroeder]. 
Packaging in Russia has almost always been ideologically and politically loaded [see for example Hilton]. This is even more true in today's, post-socialist Russia, especially in the case of vodka [Kravets; Roberts, 2014]. This is perhaps to be expected. First, for Russians, vodka is not just 'a pervasive mediator and sign of relations of sociability of all kinds', as in neighbouring Georgia [Manning, 2012, p. 183]; it is the national drink par excellence. Second, Kravets makes the important observation that 'the official ban on mass advertising [of vodka in today's Russia] makes other techniques of branding, such as naming, labelling, and packaging, a primary mode of promotion for the industry' [Kravets, p. 363]. Third, vodka is an alcoholic beverage which tends to be relatively uniform in colour, smell and taste. To quote Hine, 'it is no accident that vodka, the most characterless of spirits, has the highest profile packages' [Hine, p. 4]. With over six hundred different vodkas on the Russian market, eye-catching packaging design can help a brand both establish legitimacy and differentiate itself from the competition.

\section{Discussion (1) - Packaging}

Politically charged references were generally rare on vodka labels produced during the Soviet period. In the post-Soviet era, however, there are countless examples of ideologically loaded vodka labels, bottles and boxes. When it comes to vodka packaging design in Russia today, there are few examples more impressive than 'Legenda Kremlya' ('Legend of the Kremlin').

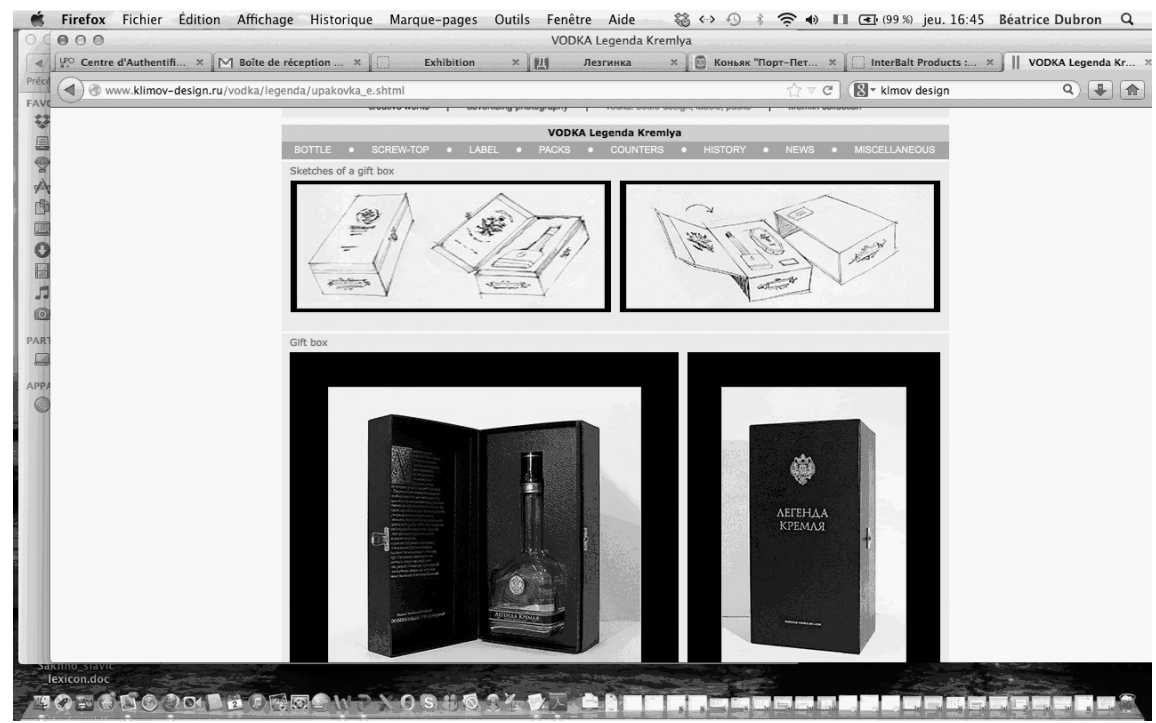

Figure 1: The box and bottle design for 'The Legend of the Kremlin' vodka (http://www.klimov-design.ru/vodka/legenda/upakovka_e.shtml) 
This vodka's long-necked bottle comes in a hollow black and gold box designed to resemble an imposing medieval manuscript (see Figure 1). When one opens the 'manuscript', the first thing one sees is the portrait of 'Monk Isidore' above the date '1430', written in an ancient calligraphic style. As one leafs further through the pages of the 'manuscript', one learns all about how Isidore stumbled across the recipe for the first Russian vodka one night working alone in his cell in the monastery that once stood on the site of the modern-day Kremlin in Moscow - the 'legend' to which the vodka's name refers. There is a reproduction of an ancient map of the Kremlin, as well as a story about the bottle itself, purportedly designed by an 'unknown craftsman' in the late eighteenth century. In sum, the story behind this brand (con)fuses the origin of vodka and the centre of Russian political power; mythologizing the brand and sacralizing the State go hand in hand in Russia.

Something similar happens with the design for the 'Russkij Led' ('Russian Ice') vodka bottle. This time, however, the glorious past to which the brand refers is military, rather than spiritual. Etched onto the bottle itself is a representation of one of the most famous battles in Russian history, namely that fought against the Teutonic Knights on a frozen Lake Peipus in 1242 (see Figure 2).

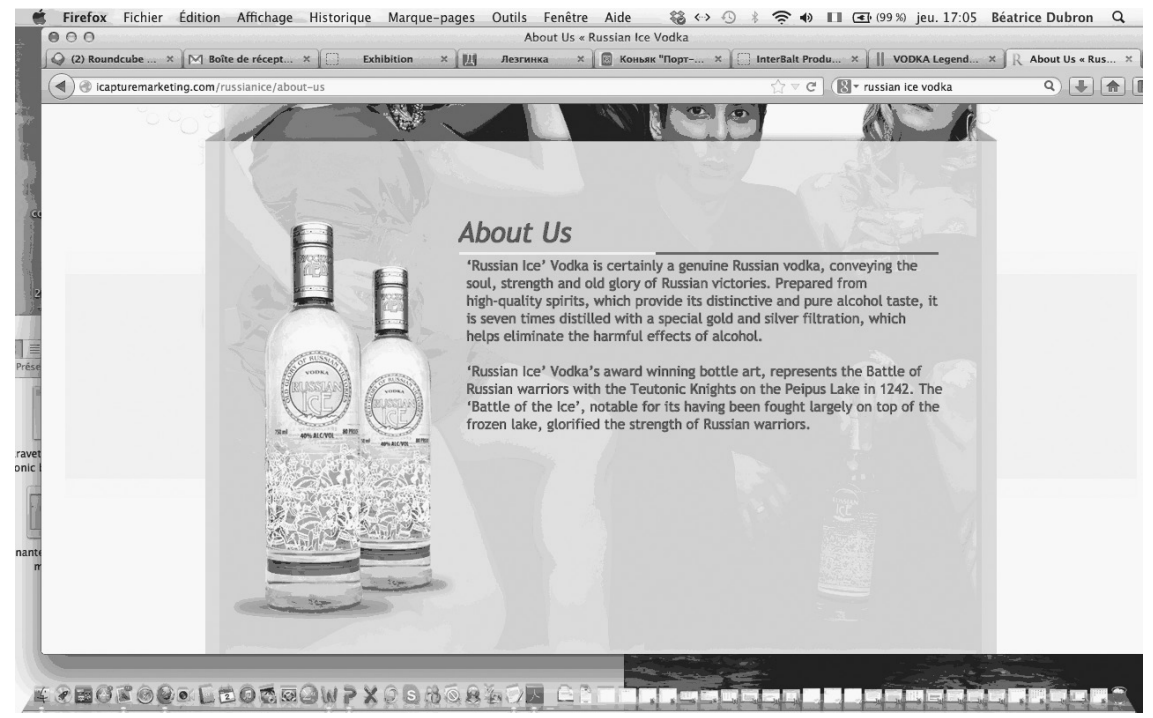

Figure 2: The bottle design for 'Russian Ice' vodka (http://icapturemarketing.com/russianice/about-us

The victory on the 'Russian Ice' is deeply imbricated with Russian national identity, since Russia's defeated enemies were finally forced to recognise the inviolability of her frontiers (its significance prompted Eisenstein to make it the centrepiece of his film Alexander Nevsky in 1936). In an 
attempt to underline still further the brand's patriotic credentials, a horizontal band of white, blue and red (the colours of the Russian flag) was added around the base of the bottle during a rebranding in 2008. In the same year, 'Russkij Led' vodka launched a press and TV advertising campaign, using Sylvester Stallone. Stallone is of course best known for his screen roles Rocky Balboa and Rambo, in which he embodied the all-American action hero - and, it should be noted, successfully fought against the 'red menace' from the East. The 'Russkij Led' ad, however, actually pointed out that Stallone's great-grandmother was Russian - from Odessa! - and claimed that 'everyone of us has a bit of Russian in them'.

'Russkij Led' is not the only alcoholic drink to celebrate the inviolability of the Russian land (although it is surely alone in insisting on the ubiquity of Russian genes). This theme is also featured on the bottle of 'Port Petrovsk' 25-year old brandy, produced since 1997 by the Derbentskij kon'yachny'j kombinat in the southern Russian republic of Dagestan. The back of the bottle tells the story of how Peter the Great arrived at the head of a fleet of ships in a quiet bay, and placed the first stone of what was to become PortPetrovsk. The ideological significance of this event is immense, since PortPetrovsk is the modern capital of Dagestan (although today it is known as Makhachkala), an autonomous, and extremely dangerous, Russian republic located in the heart of the historically disputed Caucasus, right next door to Chechnya. Significantly, the story told on the bottle of the founding of Port-Petrovsk emphasises the consensual nature of this event (Peter, we are told, places the first stone, and then invites all those accompanying him to do the same; the bottle design can be viewed at - see Figure 3).

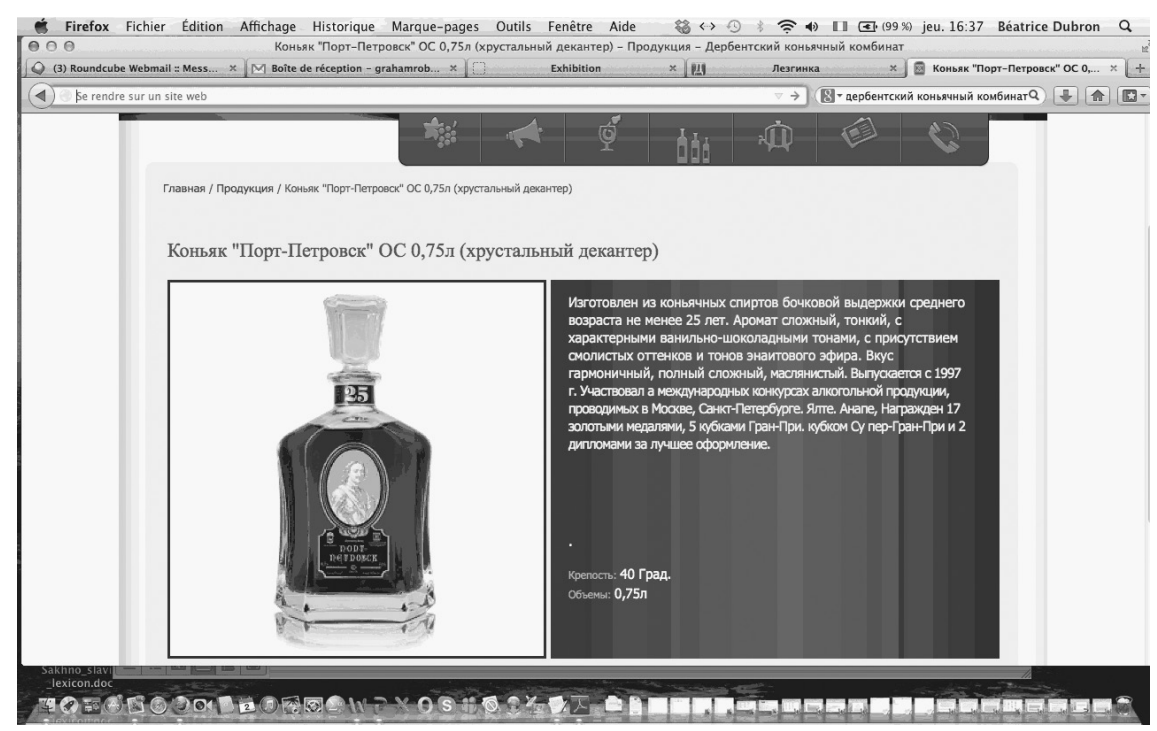

Figure 3: The bottle design for 'Port-Petrovsk' brandy (http://www.derkonyak.ru/items/65) 


\section{Discussion (2) - Social Media: the case of 'Sibirskaya korona'}

To turn now to social media, a number of Russian alcohol brands exploit consumers' patriotism and nostalgia on their social media pages. These include the vodka 'Russkij Standard', and the Russian champagne house 'Abrau-Durso'. A number of beer brands do this too, such as 'Ochakovo', which has a Facebook page devoted to its 'Muzej Tradicionny'h Russkih Napitkov' ('Museum of Traditional Russian Drinks', essentially beer and kvass). It is not difficult to explain why Russian brewers should position themselves around notions, however spurious, of national identity. It could be argued that beer is the ultimate collective tipple [Manning, 2012] which may be one reason why it has become so closely associated with national identity in other ex-Soviet republics, such as Georgia [Manning, Uplisashvili]. One of the most 'patriotic' beer brands in today's Russia is Baltika, jointly owned by brewing giants Carlsberg and Scottish \& Newcastle. In late 2004, the company launched a series of five TV advertisements which traced the progress of a group of passengers on the Trans-Siberian railway from Vladivostok to Saint Petersburg. Apart from containing shots of spectacular Russian scenery, each ad ended with the slogan 'Baltika - tam, gde Rossiya' ('Baltika - where Russia is' [see Morris, 2007]). In these remarkable advertisements, brand identity - and by extension consumer identity - is inextricably linked not to collective memories but rather to an imaginary geography. With their flagrant use of both Russian and Soviet iconography, these ads are perfect examples of what French semiotician Jean-Marie Floch calls 'mythical advertising' [Floch, p. 203; see Roberts, 2008].

The beer brand which does most to arouse Russian consumers' patriotism, however, is 'Sibirskaya korona' ('Siberian Crown'). This brand is market leader in Russia, and was voted 'No. 1 beer in Russia' in 2007 and 2009. It was launched at a local brewery, 'Rosar' in the Siberian city of Omsk in 1996, before being acquired by Russian brewer SUN Inbev in 1999. SUN Inbev in turn became part of the brand portfolio of the Belgian-Brazilian Anheuser Busch-Inbev group in 2005. According to SUN Inbev's Russian company website, 'The brand's contemporary image is based on concepts such as quality, style, pride in one's country, prosperity, generosity of spirit, and nobility'. In the early to mid 2000s it advertised aggressively in a successful attempt to transform itself from a regional, into a national brand. To quote Morris: 'Siberian Crown (Sibirskaya korona), another low-end brew, presented Imperial Russia in all its luxurious glory: candle-lit balls, splendid military uniforms and the Russian tricolour flying from every available pole' [Morris, 2007, p. 1399].

The 'Sibirskaya korona' bottle also evokes this imperial theme; the label's centrepiece is a rather ornate golden crown, set atop a dark green shape that represents Russia itself. The bottle itself is not visually striking, however - it rather resembles a Russian version of Tuborg. What makes it interesting for our purposes is that since June 2012 the brand has accelerated its transition from a regional to a national brand. And it has done so not by modifying 
the packaging, but instead thanks to a rather extraordinary use of social media sites Facebook and vkontakte. Its Facebook page, which currently has around 7,500 'friends', and its vkontakte page (over 25,000), are updated on an almost daily basis with facts, images and quotations all designed to make the viewer feel proud to be Russian. These pages are virtually identical, although for the sake of simplicity, we will focus on the Facebook page. The title of the page is 'The Map of Russian Pride', 'Karta rossijskoj gordosti', which echoes its advertising slogan, 'Est' chem gordit'sya' ('Something to feel proud about'; see Figure 4).

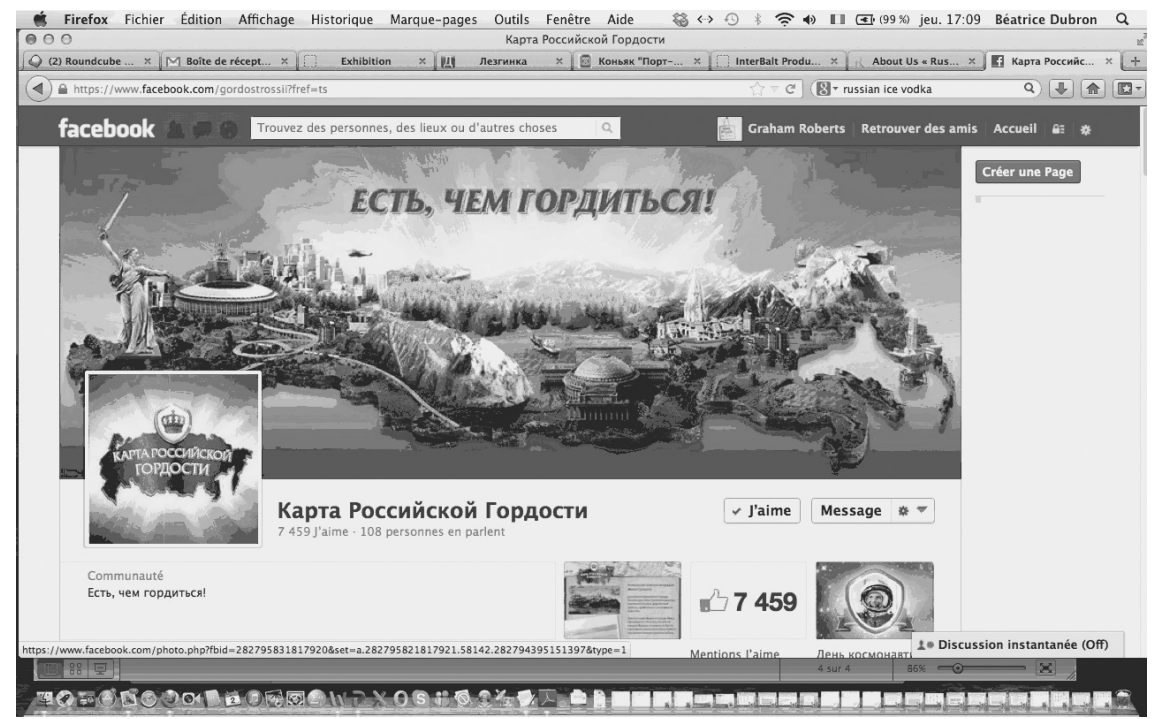

Figure 4: The 'Siberian Crown' beer Facebook home page (https://www.facebook.com/gordostrossii?fref=ts)

On this page, one finds countless photographs of, and quotations by, Russian and Soviet military heroes, artists, writers, scientists, cosmonauts and politicians (some very famous, others rather less so). Even foreign figures, such as the French General de Gaulle and Frédéric Beigbeder, are included, if they contribute to the central purpose of the page - to extol the virtues of the Russian national character, to celebrate the country's glorious past, and to make the viewer feel 'proud' to be Russian (Figure 5).

There are also countless images of natural features, such as Lake Baikal, or man-made structures, such as the fountains at Peterhof, or the Sochi 2014 Winter Olympics stadium. No opportunity is lost to compare Russia favourably with the West -we learn, for example, that Moscow' Ostankino TV tower is much higher than New York's Empire State Building. The 'Sibirskaya korona' page makes little or no distinction between Soviet and pre-Soviet eras. For example, on 17 February 2013, there was a quotation 
from $19^{\text {th }}$-century writer Nikolay Gogol, next to a reference to the cosmodrome at Bajkonur and the exploits of Yury Gagarin (Figure 6).

While most of the time, these quotations are so generalising as to be practically meaningless, sometimes they can be highly tendentious - as for example, the quotation by Russian aphorist Konstantin Kushner (born 1944), suggesting cultural similarities between Russia, Ukraine and Belorussia. Most recently, to coincide with $68^{\text {th }}$ anniversary of the end of the Great Patriotic War, and victory over Nazi Germany, the company has launched a sub-page, entitled 'Pobeda, kotoroj my' gordimsya' ('A victory to feel proud about': Figure 7).

A post on the main page contains the following: 'Thank you for your victory! The Great Patriotic War [= WWII] touched every family. For each 'like' on the page http://pomnim-pobedu.ru/ we will donate one rouble to the monument renovation fund! Share the post with your friends and help renovate these monuments to a great Russian victory, the victory of our forefathers!'. These monuments are in the goroda-geroi (hero-cities) of Moscow, St Petersburg, Nizhny Novgorod and Volgograd (Figure 8).

In the summer of 2013, the brand published dozens of photographs of citizens from its home city of Omsk, holding up placards claiming Omsk as the capital of 'Eurasia' - a barely hidden allusion to President Putin's oftrepeated desire to see Russia at the head of an Eastern political alliance to counterbalance Western (and particularly US) socio-economic hegemony.

The different ways in which Sibirskaya korona's numerous Facebook 'friends' interact with it, through their likes, their (overwhelmingly positive) comments and their shares, and by agreeing to appear themselves on the page in the series of Omsk photographs, underline the fact that branding is as much about constructing the consumer's identity, as it is concerned with positioning the brand itself. We might even go so far as to say that what links packaging and social media networks - at least those examples discussed here - is precisely the 'dialectic of mutual creation' that Miller sees as central to material culture [Miller, 2010, p. 114]. Of course, from the brand's point of view, there is a crucial difference between packaging and social media: the higher the number of 'dislikes' and negative posts on a brand's Facebook, vkontakte or YouTube page, the more control of the brand will pass from managers to consumers [see Champoux, Durgee, McGlynn]. In the Web2.0 era, brand managers ignore at their peril the threats posed by what Pongsakornrungslip and Schroeder refer to as 'coconsuming brand communities' [Pongsakornrungslip, Schroeder].

\section{Conclusion}

To conclude, in his ground-breaking article on Russian cigarette advertising in the Yeltsin era, Morris made the following comment: 'both Russian and multinational companies have attempted to connect the brand identity 


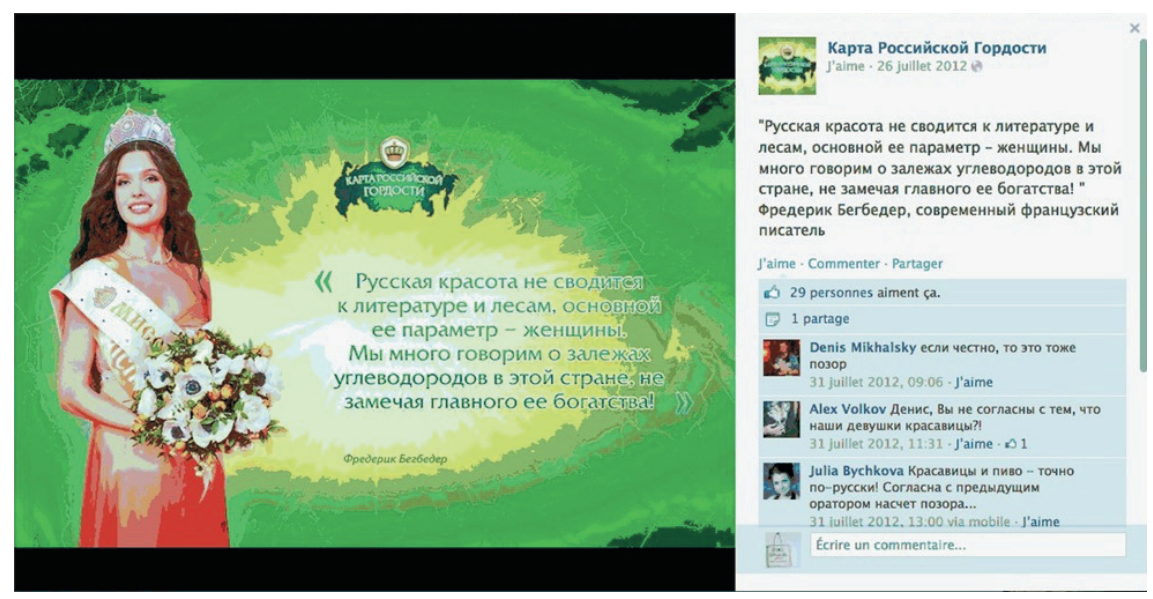

Figure 5: A post quoting French novelist Frédéric Beigbeder praising the beauty of Russian women

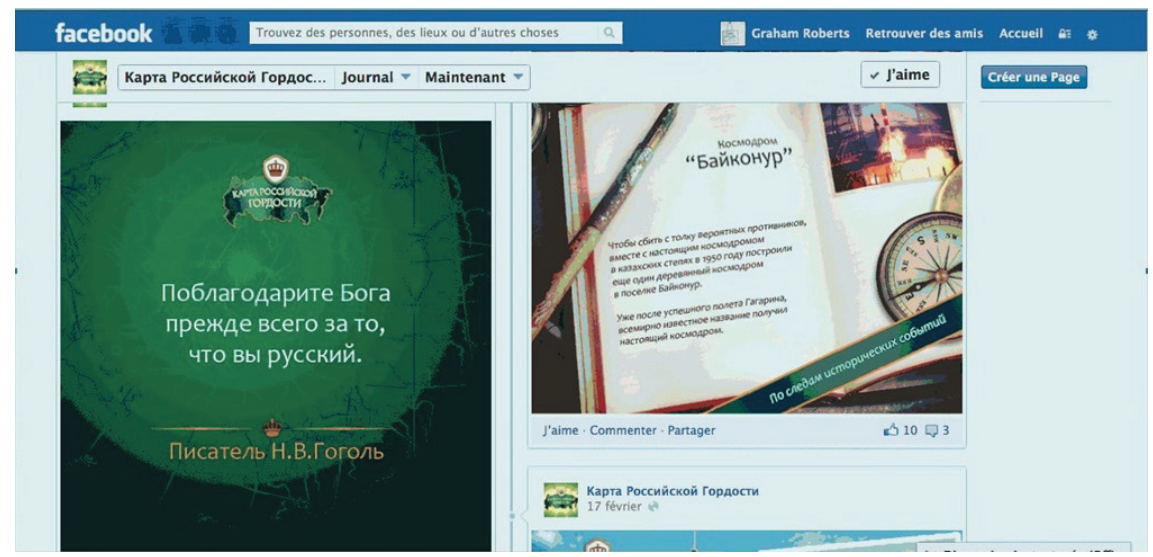

Figure 6: From Gogol to Bajkonur 


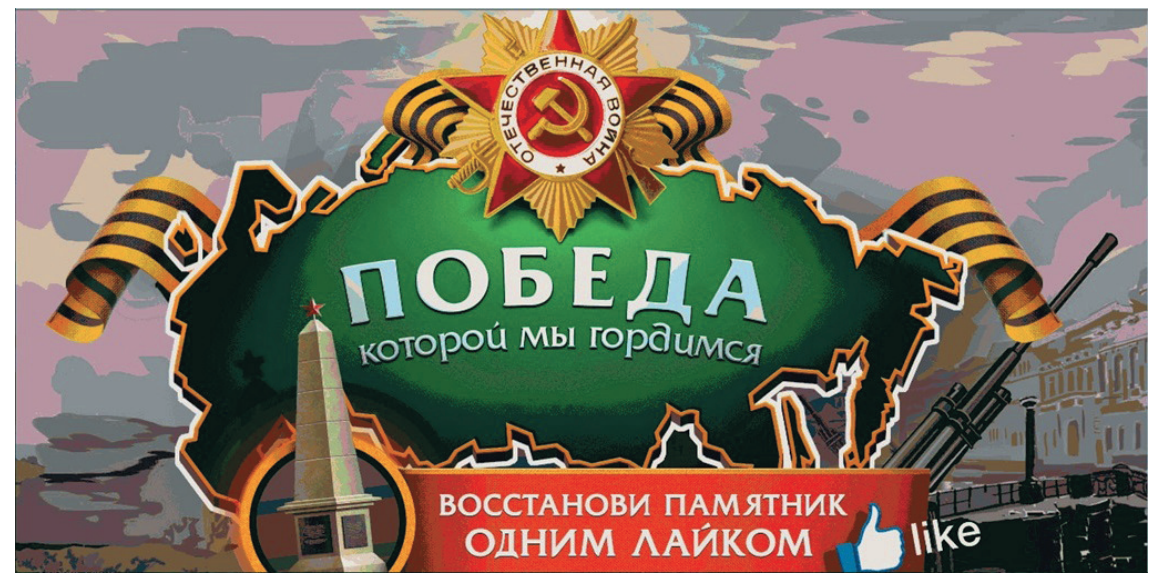

Figure 7: 'A Victory We Are Proud Of'

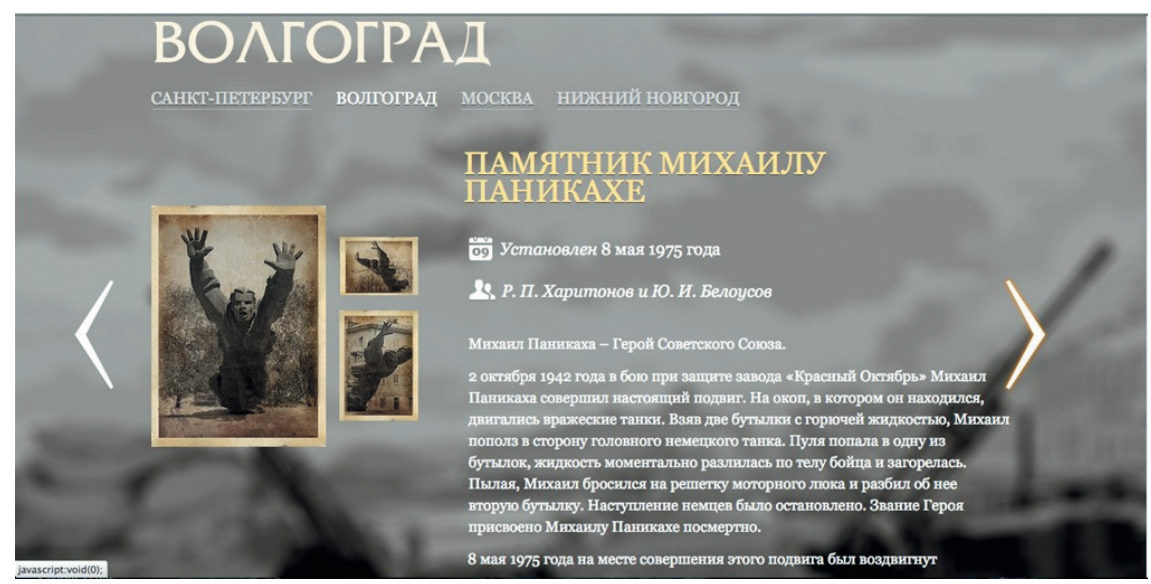

Figure 8: The 'Volgograd' page from the 'Victory' series, which tells the story of Mihail Panikaha, and the monument dedicated to his memory 
of products to national origin and national identity' [Morris, 2005, p. 660]. Our brief survey suggests that this phenomenon is just as much a feature of post-socialist Russian packaging and social media sites as it is of advertising - at least where alcohol is concerned. Since the collapse of the USSR, and especially since the rise to power of Vladimir Putin, a number of alcohol brands have positioned themselves around the myth of the Great Russian Past. In an unpredictable age, Russia emerges as the ultimate umbrella brand, a welcome source of reliability and reassurance for the Russian consumer in today's troubled times [Sabonis-Chafee]. Reproducing and representing political discourses in the broader public sphere, the brands under discussion here all resemble Douglas Holt's 'iconic brands' [Holt, p. 374], in as much as they behave like 'mercenaries, following ideological demands wherever the action is' [see also Kravets, Örge]. All countermemories that might not concord with the hegemonic view of the Great Russian Past are simply effaced.

The 'Legenda Kremlya' vodka box and the 'Karta Rossijskoj gordosti' Facebook page are clearly meant to appeal to Russian consumers' nostalgic (not to say nationalistic) belief in their country's great past, and may even serve to reinforce their belief in the possibility of a bright new future, a new imperial age. It is very hard not to see the re-emergence of Russian national symbols and myths as an expression of what Boym calls 'restorative nostalgia'. In uncertain times, Boym argues, restorative nostalgia 'proposes to rebuild the lost home and patch up the memory gaps' [Boym, p. 41]. 'Moreover', she continues, 'the past is not supposed to reveal any signs of decay; it has to be freshly painted in its "original image" and remain eternally young' [Boym, p. 49]. Such nostalgia works for Boym rather like myth for Lévi-Strauss [1968], who argues that mythical thought helps to resolve the tension between on the one hand our idea of the world, and on the other our practical, everyday experience of that world. We are not suggesting, of course, that this is part of a concerted political programme. Rather we would agree with Oushakine's point [Oushakine, p. 453] that 'the cultural logic of these reincarnations has more in common with the act of mechanical retrofitting (facilitated by the digital age) rather than with the process of political restoration.'

Not only do they mythologize Russia and the Russian past, however; these brands also help construct the identity of consumers, since they appeal to consumers' collective sense of self [Hollenbeck, Kaikati]. They materialise - often literally - social relationships, as Fehérváry puts it [Fehérváry, p. 429]. One might even say, following Miller [1987], that they 'objectify' collective memories and national identity (on the Internet as a form of 'objectification', see also [Miller, 2010, p. 118]). Hine is surely right when he observes that 'packaging provides a way in which people define and understand themselves' [Hine, p. 202]. However, one could say much the same thing about social media networks such as 'Sibirskaya korona"s, inasmuch as they appear to be taking over the function of packaging in today's networked, immaterial world [Kaplan, Haenlein]. In other words, 
to purchase 'Russkij Led' vodka or share a post on the 'Sibirskaya korona' Facebook page is - consciously or unconsciously - to buy into a discourse about Russia as a nation, and thereby about one's own identity as a Russian.

Brands such as 'Russkij Led' may well seek to cover themselves in glory by depicting famous Russian military victories on their bottles, or underlining the Russian heritage of celebrated US actors in their advertisements. 'Sibirskaya korona', on the other hand, are discovering that when it comes to what Miller calls the 'ar[t] of seduction' [Miller, 2010, p. 114], exploiting social media can be a much more effective communication strategy. In the light of our discussion, more work clearly needs to be done on the relationship first, between material culture and immaterial culture (or the 'materiality of digital worlds', to quote Miller and Horst [2012]); second, between material culture and 'brand culture' [Askegaard]; and third between mythologizing the brand and sacralising the nation state.

Askegaard S. Brands as a global ideoscope // Brand culture / ed. by J. E. Schroeder, M. Salzer-Mörling. Abingdon; New York : Routledge, 2006.

Borgerson J., Schroeder J. Packaging paradise: Sonic branding of the south pacific [Electronic resource] // Material World : [blog]. 2008. URL: http://www.materialworldblog.com/2008/04/packaging-paradise-sonic-branding-of-the-south-pacific/ [Accessed 19.10.2013].

Boym S. The future of nostalgia. New York : Basic Books, 2001.

Champoux V., Durgee J., McGlynn L. Corporate Facebook pages: When 'fans' attack. // Journal of Business Strategy. 2012. Vol. 33. No. 2. P. 22-30.

Fehérváry K. Goods and states: The political logic of state-socialist material culture // Comparative Studies in Society and History. 2009. Vol. 51. No. 2. P. 426-459.

Floch J.-M. Sémiotique, marketing et communication: Sous les signes, les stratégies. Paris : Presses Universitaires de France, 1990.

Glass A. The material culture of (n)ostalgie [Electronic resource]. 2012. URL: http:// www.materialworldblog.com/2012/04/the-material-culture-of-nostalgie/ [Accessed 19.10.2013].

Heilbrunn B., Barré B. Le packaging. Paris: Presses Universitaires de France, 2012.

Hilton M. L. Selling to the masses: Retailing in Russia, 1880-1930. Pittsburgh : University of Pittsburgh Press, 2012.

Hine Th. The total package: The secret history and hidden meanings of boxes, bottles, cans, and other persuasive containers. Boston : Back Bay Press, 1995.

Hollenbeck C. R., Kaikati A. M. Consumers use of brands to reflect their actual and ideal selves on Facebook // International Journal of Research in Marketing. 2012. Vol. 29. No. 4. P. 395-405.

Holt D. B. Jack Daniel's America: Iconic brands as ideological parasites and proselytizers // Journal of Consumer Culture. 2006. Vol. 6. No. 3. P. 355-377.

Kaplan A. M., Haenlein M. Two hearts in three-quarter time: How to waltz the social media/viral marketing dance // Business Horizons. 2011. Vol. 54. No. 3. P. 253-263.

Kravets $O$. Russia's 'pure spirit': Vodka branding and its politics // Journal of Macromarketing. 2012. Vol. 32. No. 4. P. 361-376.

Kravets O., Örge Ö. Iconic brands // Journal of Material Culture. 2010. Vol. 15. No. 2. P. 205-232.

Lévi-Strauss C. Structural anthropology. London : Allen Lane, 1968.

Makarenko K., Borgerson J. Ice cream and "CCCP": Evoking nostalgia in post-soviet packaging [Electronic resource]. 2009. URL: http://www.materialworldblog.com/2009/05/ ice-cream-and-cccp-evoking-nostalgia-in-post-soviet-packaging/ [Accessed 19.10.2013].

Manning P. The semiotics of brand // Annual Review of Anthropology. 2010. Vol. 39. P. $33-49$. 
Manning $P$. The semiotics of drink and drinking. London ; New York : Continuum Books, 2012.

Manning P., Uplisashvili A. 'Our beer': Ethnographic brands in postsocialist Georgia // American Anthropologist. 2007. Vol. 109. No. 4. P. 626-641.

Miller D. Material culture and mass consumption. Oxford : Basil Blackwell, 1987.

Miller D. Stuff. Cambridge : Polity, 2010.

Miller D., Horst H. A. Introduction. The digital and the human: A prospectus for digital anthropology // Digital Anthropology / ed. by H. A. Horst, D. Miller. London ; New York : Berg, 2012.

Morris $J$. Drinking to the nation: Russian television advertising and cultural differentiation // Europe-Asia Studies. 2007. Vol. 59. No. 8. P. 1387-1403.

Morris J. The empire strikes back: Projections of national identity in contemporary Russian advertising // The Russian Review. 2005. Vol. 64 (October). P. 642-660.

Oushakine S. A. 'We're nostalgic but we're not crazy': Retrofitting the past in Russia // The Russian Review. 2007. Vol. 66 (July). P. 451-482.

Pongsakornrungslip S., Schroeder J. E. Understanding value co-creation in a co-consuming brand community // The Marketing Review. 2011. Vol. 11. No. 3. P. 303-324.

Roberts G. It's (im)material: Packaging, social media and iconic brands in the new Russia [Electronic resource]. 2013. URL: http://www.materialworldblog.com/2013/09/ its-immaterial-packaging-social-media-and-iconic-brands-in-the-new-russia/ [Accessed 21.10.2013].

Roberts G. Message on a bottle: Packaging the Great Russian Past // Consumption, Markets and Culture. (Forthcoming). 2014.

Roberts $G$. Palimpsestes ou âmes mortes? La russification des marques européennes de grande consommation [Electronic resource]. 2008. URL: http://institut-est-ouest.ens-lsh.fr/ spip.php?article129 [Accessed 19.10.2013].

Sabonis-Chafee T. Communism as kitsch: Soviet symbols in post-soviet society // Consuming Russia: Popular culture, sex, and society since Gorbachev / ed. by A. M. Barker. Durham ; London : Duke University Press, 1999.

Schroeder J. E. Visual Consumption. London; New York : Routledge, 2002.

Woodward I. Understanding Material Culture. Los Angeles ; London : Sage, 2007.

Askegaard, S. (2006). Brands as a global ideoscope. In J. E. Schroeder, M. SalzerMörling (Eds.), Brand culture. Abingdon and New York: Routledge.

Borgerson, J. \& Schroeder, J. (2008). Packaging paradise: Sonic branding of the south pacific. Material World [blog]. Retrieved from http://www.materialworldblog.com/2008/04/ packaging-paradise-sonic-branding-of-the-south-pacific/ (last accessed on 19.10.2013).

Boym, S. (2001). The future of nostalgia. New York: Basic Books.

Champoux, V., Durgee, J. \& McGlynn, L. (2012). Corporate Facebook pages: When 'fans' attack. Journal of Business Strategy, 33, 2, 22-30.

Fehérváry, K. (2009). Goods and states: The political logic of state-socialist material culture. Comparative Studies in Society and History, 51, 2, 426-459.

Floch, J.-M. (1990). Sémiotique, marketing et communication: Sous les signes, les stratégies. Paris: Presses Universitaires de France.

Glass, A. (2012). The material culture of (n) ostalgie. Retrieved from http://www.materialworldblog.com/2012/04/the-material-culture-of-nostalgie/

Heilbrunn, B. \& Barré, B. (2012). Le packaging. Paris: Presses Universitaires de France.

Hilton, M. L. (2012). Selling to the masses: Retailing in Russia, 1880-1930. Pittsburgh: University of Pittsburgh Press.

Hine, Th. (1995). The total package: The secret history and hidden meanings of boxes, bottles, cans, and other persuasive containers. Boston: Back Bay Press.

Hollenbeck, C. R. \& Kaikati, A. M. (2012). Consumers use of brands to reflect their actual and ideal selves on Facebook. International Journal of Research in Marketing, 29, $4,395-405$.

Holt, D. B. (2006). Jack Daniel's America: Iconic brands as ideological parasites and proselytizers. Journal of Consumer Culture, 6, 3, 355-377.

Kaplan, A. M. \& Haenlein, M. (2011). Two hearts in three-quarter time: How to waltz the social media/viral marketing dance. Business Horizons, 54, 3, 253-263. 
Kravets, O. (2012). Russia's 'pure spirit': Vodka branding and its politics. Journal of Macromarketing, 32, 4, 361-376. 232.

Kravets, O. \& Örge, Ö. (2010). Iconic brands. Journal of Material Culture, 15/2, 205-

Lévi-Strauss, C. (1968). Structural anthropology. London: Allen Lane.

Makarenko, K. \& Borgerson, J. (2009). Ice cream and "CCCP": Evoking nostalgia in post-soviet packaging. Retrieved from http:/www.materialworldblog.com/2009/05/icecream-and-cccp-evoking-nostalgia-in-post-soviet-packaging/

Manning, P. (2010). The semiotics of brand. In Annual Review of Anthropology. (Vol. 39 , pp. 33-49).

Manning, P. (2012). The semiotics of drink and drinking. London and New York: Continuum Books.

Manning, P. \& Uplisashvili, A. (2007). 'Our beer': Ethnographic brands in postsocialist Georgia. American Anthropologist, 1094, 626-641.

Miller, D. (1987). Material culture and mass consumption. Oxford: Basil Blackwell.

Miller, D. (2010). Stuff. Cambridge: Polity.

Miller, D. \& Horst, H. A. Introduction. (2012). The digital and the human: A prospectus for digital anthropology. In H. A. Horst \& D. Miller (Eds.), Digital Anthropology. London and New York: Berg.

Morris, J. (2005). The empire strikes back: Projections of national identity in contemporary Russian advertising. In The Russian Review. (Vol. 64, pp. 642-660).

Morris, J. (2007). Drinking to the nation: Russian television advertising and cultural differentiation. Europe-Asia Studies, 59, 8, 1387-1403.

Oushakine, S. A. (2007) 'We're nostalgic but we're not crazy': Retrofitting the past in Russia. In The Russian Review. (Vol. 66, pp. 451-482).

Pongsakornrungslip, S. \& Schroeder, J. E. (2011). Understanding value co-creation in a co-consuming brand community. The Marketing Review, 11, 3, 303-324.

Roberts, G. (2008). Palimpsestes ou âmes mortes? La russification des marques européennes de grande consommation. Retrieved from http://institut-est-ouest.ens-lsh.fr/spip. php?article129

Roberts, G. (2013). It's (im)material: Packaging, social media and iconic brands in the new Russia. Retrieved from http://www.materialworldblog.com/2013/09/its-immaterialpackaging-social-media-and-iconic-brands-in-the-new-russia/

Roberts, G. (2014). Message on a bottle: Packaging the Great Russian Past. In Consumption, Markets and Culture. (Forthcoming).

Sabonis-Chafee, T. (1999). Communism as kitsch: Soviet symbols in post-soviet society. In A. M. Barker (Ed.), Consuming Russia: Popular culture, sex, and society since Gorbachev. Durham and London: Duke University Press.

Schroeder, J. E. (2002). Visual Consumption. London and New York: Routledge.

Woodward, I. (2007). Understanding Material Culture. Los Angeles and London: Sage.

The article was submitted on 30.04.2014

\author{
Грэхам Робертс, $\mathrm{PhD}$ \\ Франция \\ Университет \\ Париж X - Нантер \\ groberts@u-paris10.fr
}

\author{
Graham H. Roberts, PhD \\ France, Paris Ouest Nanterre \\ La Défense \\ groberts@u-paris10.fr
}

